\section{Trade Relations Between Ancient Bacteria And China On The II-I BC}

(Based On Ancient Chinese Sources And Archeological Materials)

\section{Ismatullayeva Nargiza Rasuljanovna, Karimov Nodir Rakhmonqulovich}

PhD Student, Tashkent State University of Oriental Studies, Uzbekistan

\begin{abstract}
G OPEN ACCESS
The American Journal of Social Science And Education Innovations JULY 2020

Page No.: 47-51

Volume-II Issue-VII

PUBLISHED: 30 JULY 2020 www.usajournalshub.com/inde x.php/tajssei

Copyright: Original content from this work may be used under the terms of the Creative Commons Attribution 4.0 licence.
\end{abstract}

\begin{abstract}
This article is devoted to the study of trade relations between the Khan dynasty of ancient Bactria, which ruled in ancient Afghanistan in the II-I centuries BC, located in the territories of northern Afghanistan, southern Uzbekistan, southwestern Tajikistan. The data are based on ancient Chinese sources and materials obtained as a result of archeological excavations carried out in Afghanistan in the twentieth century.
\end{abstract}

Keywords: Ancient Bactria, Khan Dynasty, II-I centuries BC, trade relations, ancient Chinese sources, archeological materials.

\title{
Introduction
}

As a crossroads of ancient world civilizations, Afghanistan is one of the most important places on the Great Silk Road, uniting Greece and Persia in the west, India in the south, and China in the east in trade and diplomatic relations. It is here that a multifaceted culture with a unique appeal has been formed since ancient times.

It is well known that archeological sources, based on historical materials and supported by concrete facts, are mined underground. In its depths, the Earth holds various invaluable materials for human history. The task of archeology is to reconstruct history, the past, on the basis of factual historical materials, which are also reliable. In this sense, this article examines the development of trade relations between Ancient Bactria and Ancient China, part of which is located in the territory of Afghanistan, and the results of archeological excavations. 
Ancient Bactria is located on the two banks of the upper reaches of the Amudarya river. Historian, academician A. Askarov, based on modern ethnographic ideas, shows that the borders of this country correspond to the territories of Northern Afghanistan, Southern Uzbekistan, and South-Western Tajikistan [1, 2018].

\section{The Main Findings And Results}

In ancient Chinese sources, Bactria is given the name "Dasya" (大夏). According to historical records [2], the people of Bactria lived a sedentary life. The people were very adept at trade. The capital of Bactria was Lanshicheng (Blue City), where there was a market where various goods were sold [3, 2001].

In his report, Zhang Chian, who was sent by the Khan dynasty on a mission to establish diplomatic relations with Central Asian states in the 2 nd century BC, wrote about the routes from China to countries west of India, India, Iran and even the Caspian Sea [4, 1997]. According to Zhang Chiang's report, while in Bactria, he saw a cane made of bamboo growing on Mount Chyung (IP) and a fabric made in the same country. He informs the emperor that it is convenient and safe to travel through Sichuan, knowing that these are brought by Bactrian merchants from India [5, 2013].

Such information, given in ancient Chinese sources, indicates that trade in Ancient Bactria was well-established, as were trade relations with neighboring regions. It is also possible that such relations took the form of "diplomatic trade".

It is known that in ancient times the form of barter occurred as a result of the exchange of mutual gifts between rulers with the help of ambassadors. R. Mirzaev notes that trade on the Great Silk Road is also called "diplomatic trade" [6, 2005]. Gradually, the exchange of official gifts, disguised as a diplomatic form, is replaced by simple private trade $[7,2013]$.

As for the direct archeological results, which serve as evidence for this information, in the twentieth century, archeological excavations in Central Asia, East Turkestan and China intensified. These archeological researches not only confirmed the data from ancient written sources, but also testified too many unwritten historical events.

According to Academician A.Askarov, in 1921 a French archeological expedition led by A.Fush was organized in Afghanistan to find the treasures of Ancient Bactria. Archaeological excavations have uncovered the remains of royal palaces, temples adorned with treasures and statues. Instead of continuing the excavations more extensively, A. Fush denies that the information about the mighty Ancient Bactrian state and its rich culture is false. The invalidity and futility of such Eurocentric historical views, which prevailed at the beginning of the last century, was revealed in the example of unique monuments of the Bronze Age - Sopollitepa, Jarqoton, Boston and other cultures [1, 2018].

In 1979, a tomb of aristocrats with ancient Bactrian artifacts was found in the ruins 
of Tillatepa, 5 kilometers northeast of Sibarkand in northern Afghanistan. In the ruins there is a tomb full of six tongues in a row $[9,1995]$. Tombs $2,3,6$ belong to the same period. Because all three tombs were excavated in the basin of the Huanghe River between the reigns of Emperor Khan Xuandi of the Western Khan Dynasty (73-49 BC) and Khan Pingdi (1-5 BC). Several more bronze vessels were excavated from the tombs. It is noted that their shape is similar to the bronze vessels of the Khan dynasty [10, 1995].

Lin Maitsun notes that the Jaoming bronze mirrors were undoubtedly brought to Bactria via the Silk Road. However, it should be noted that according to the brief generalization of archaeologist L.M. Sverchkov "Xinjiang Archeology", In about 20001500, the Bactria-Margiyana archeological complex, located in western Turkmenistan, southern Uzbekistan and northern Afghanistan, produced bronze on the basis of arsenic in the culture of the Bronze Age Amudarya. According to this information, in the Central Asian region there was a craft of bronze, and by the II century BC there was a craft of making various items from it, as well as the craft of making mirrors $[11,2016]$. Therefore, the archeological excavations in Central Asia Not all second-century bronze items can be said to have come from China. This can only be proved by the degree of similarity of the item to the Chinese item, based on the material composition of the bronze.

In 1936, a large quantity of silk from the Khan period of China was found in an ancient ruin in Bactria, north of Kabul, Afghanistan [12, 2001]. Afghanistan's tombs at Tillatepa are also lined with silk or taffeta cloth [13, 1995].

From the book "History of the Khan's Dynasty" by A. Khodjaev, an ambassador or trader who went to the West should carry as much silk as possible. Otherwise, he says, "he may not even be able to find food to eat," noting that in ancient times, silk was not only China's main export, but also a means of payment for goods bought from other nations [14, 2007].

In Central Asia, a large number of small tables and glasses lacquered among Chinese imports have been found. Fragments of such artifacts were found in the firstcentury $A D$ cemeteries in the Zhetysu in the Chu and Talas river valleys [15, 1990], while lacquered boxes, lacquered plates, and lacquered earrings were found in the ruins of Pageman (Buddhist temple $[16,2001]$ ) excavated about $7 \mathrm{~km}$ north of Kabul (Afghanistan) [17, 1997].

\section{Conclusion}

To conclude, we can say from ancient Chinese sources that trade relations between Ancient Bactria and China were well established in the II-I centuries BC, and the territory of present-day Afghanistan was one of the leading points connecting East and West in trade and diplomatic relations. The development of such relations is also evidenced by the material evidence found during archeological excavations in Central Asia, especially in Afghanistan, in the twentieth century.

\section{References}


[1]. Askarov A. (2018) History of the origin of the Uzbek people. - Tashkent. Uzbekistan. - p. 181.

[2]. 史记》Shiji - "Historical Notes" was written by the historian of the Khan dynasty Sima Qian (司马迁 Sima Qian 145-87 BC), The historical data in the work is from the semiauthentic, semi-mythical period of antiquity - from the reign of the legendary Huangdi (黄帝 Huangdi -13th millennium BC) to the Khan emperor Udi ( $140-87$ BC). The play depicts historical events in the fields of politics, economics and culture.

[3]. Sima Qian zhu, Yang Yanqi zhuyi. (2001) Shiji quanyi. - Guiyang: Guizhou renmin chubanshe. - Pp. 42-57.

[4]. Swen Heding (Ruidian). Sichou zhi lu. / Hong Jiang, Li Peijuan yi. (1997) - Wulumuqi: Xinjiang renmin chubanshe. - p. 209.

[5]. Khojaev A. (2013) Information on the history of Fergana: Translations and commentaries from ancient and early medieval Chinese sources. - Fergana. "Fergana" publishing house. - p. 40.

[6]. Mirzaev R. Genesis and evolution of the Great Silk Road. "Browser-Observer". 2005. No. 7. http://observer.materik.ru/observer/N7_2005/7_16.HTM

[7]. Barinova E.B. (2013) Ethno-cultural contacts of China with the peoples of Central Asia in antiquity and the Middle Ages. - Moscow. IEA RAS. - p. 178.

[8]. Lin Meicun. (1995) Xiyu wenming: kaogu, minzu, yuyan he zongjiao xinlun. - Beijing: Dongfang chubanshe. - pp. 267, 273, 274-275.

[9]. Lin Meicun. (1995) Xiyu wenming: kaogu, minzu, yuyan he zongjiao xinlun. - Beijing: Dongfang chubanshe. - pp. 274-275.

[10]. Sverchkov L.M. (2016) Xinjiang Archeology (Short Review). BEIP "Suyun"; Vol. 3. No. $11(1,2)$. - From 923.

[11]. Xia Xiurui, Sun Yuqin. (2001) Zhongguo duiwai maoyi shi (di yi ce). - Beijing: Duiwai jingji maoyi daxue chubanshe. - p. 27.

[12]. Lin Meicun. (1995) Xiyu wenming: kaogu, minzu, yuyan he zongjiao xinlun. Beijing: Dongfang chubanshe. - pp. 274-275.

[13]. Khojaev A. (2007) The Great Silk Road: Relationships and Destinies. - Tashkent. National Encyclopedia of Uzbekistan. - pp. 177-179.

[14]. Rtveladze E. (1990) The Great Silk Road: Encyclopedic Reference: Antiquity and Earlier the Middle Ages. - Tashkent. "Uzbekistan Milly Encyclopedia". - p. 132.

[15]. Xia Xiurui, Sun Yuqin. (2001) Zhongguo duiwai maoyi shi (di yi ce). - Beijing: Duiwai jingji maoyi daxue chubanshe. - p. 34. 


\section{THE AMERICAN JOURNAL OF SOCIAL SCIENCE AND EDUCATION INNOVATIONS}

ISSN (e): 2689-100X

DOI: https://doi.org/10.37547/tajssei/Volume02Issue07-04

[16]. Li Mingwei. (1997) Sichou zhi lu maoyi shi. - Lanzhou: Gansu renmin chubanshe. p. 44.

[17]. Oblomurodov Naim Khalimovich, Ismatullayeva Nargiza Rasuljanovna, Goyibnazarov Isobek Shakarovich. THE PURPOSE AND OUTCOME OF DIPLOMATIC MISSIONS IN THE II-I CENTURIES BETWEEN CENTRAL ASIA AND CHINA. JCR. 2020; 7(9): 126128. doi:10.31838/jcr.07.09.23

[18]. Karimov N.R. (2019) The contribution of Bernd Radtke on the studying Hakim Tirmidhi's scientific heritage. European Journal of Research, 1/12, - pp.95-103

[19]. Karimov N.R. (2018) Some researches on Abu Isa Tirmidhi in European countries. International Journal of Current Research, 10/12, pp. 76170-76173 